\title{
The Succession and Regression of Plant Species on Lowland Hay Meadows in Poland
}

\author{
Maciej Brzank*, Kazimierz Piekut, Piotr Dąbrowski, Bogumiła Pawluśkiewicz \\ Warsaw University of Life Sciences - SGGW, Faculty of Civil and Environmental Engineering, \\ Department of Environmental Improvement, Warsaw, Poland
}

Received: 28 January 2018

Accepted: 11 April 2018

\begin{abstract}
Our paper presents the results of research conducted in the Mala River Valley located $22 \mathrm{~km}$ south of Warsaw, Poland. The study examines successional changes under different management regimes in natural meadow habitats included in the European Union's Natura 2000 network. The meadow species composition, structure, and diversity in areas mown early, late, sporadically, and the unmown ones were examined. Changes in the natural habitat and woody vegetation areas were also analysed. The results showed a $40 \%$ reduction in natural habitat and a $57 \%$ increase in woody vegetation coverage over a six-year period, which indicates rapid and progressive succession. The increases in abundance of Deschampsia caespitose, Alopecurus pratensis, Holcus lanatus, and Anthoxanthum odoratum indicated the progressive degradation of fresh hay meadow communities attributed to the cessation of mowing. The expansive species Urtica dioica increased in abundance and persistence with reduced mowing intensity. Alien species such as Solidago canadensis and S. gigantea were noticed mainly in abandoned areas for at least five years.
\end{abstract}

Keywords: Natura 2000, Arrhenatherion, grassland management, preservation perspective, post-boggy habitat

\section{Introduction}

Halting the loss of biodiversity and the degradation of ecosystem services in the EU by 2020 and restoring them so far as feasible are the targets of the EU Biodiversity Strategy [1]. The core element of the preservation of European most endangered species and the valuable natural habitats across their entire natural range within the EU is the Natura 2000 network [2]. It covers $18,15 \%$ of land area UE-28 and $19,56 \%$ of land area in Poland [3]. Agricultural land

*e-mail: maciej_brzank@sggw.pl makes up around $40 \%$ of the total area included in Natura 2000 in the UE, and in Poland around 35\%. [4]. In the last 50 years, through the combined effects of farm intensification and land abandonment, farmland biodiversity has undergone a dramatic decline $[5,6]$. Most of the farmland in Natura 2000 is located in the more marginal farming areas [7]. Restoring, preserving, and enhancing biodiversity are the current priorities of the UE Policy of Rural Development [8].

Lowland grasslands in Poland, just like in other European countries, are the effects of human activity, forest clearance and, to a lesser extent, burns and wetland drainage, conducted to provide fodder for domestic livestock. The plant species occurring presently in semi-natural grasslands have probably originated 
from the woodland ground flora, covering open habitats such as sand-dunes, which were maintained by natural catastrophes and grazing by native herbivores, as well from the drier edges of wetlands. They are protected on Natura 2000 areas under the Habitat Directive as natural habitat 6510 lowland hay meadows.

Lowland hay meadows are generally the floristically richest agricultural lands in Europe [9, 10] because of the diversity of occupied habitats. They cover various types of soils, from fertile fine brown, muddy-silt, and muddy-peat to drying or drained peat to muck ones. The floristic composition of lowland hay meadows beyond site properties (fertility) and water conditions is affected by the methods and intensity of agricultural management. Grazing and cutting have been important factors in both the creation and maintenance of these grasslands. These plant communities react dynamically to changes in environmental conditions [11]. Annual mowing and grazing play a crucial role in maintaining stability and preventing degradation of vegetation [1116]. The abandonment of meadow agricultural use is considered one of the basic reasons for the vanishing and deterioration of conservation status [17-19]. But in many cases the recession of species valuable for cattle feeding from the sward (meadow vegetation) and succession of unpalatable species or even toxic ones, which limited the possibility of their utilisation in livestock feeding, have been the primary reasons for the cessation of grassland management [20]. The monitoring conducted by the Main Inspectorate of Environment Protection in 20092011 has shown that the conservation status of natural habitats 6510 is in $61 \%$ unfavourable-inadequate, in $20 \%$ unfavourable-bad, and only in 19\% favourable [21].

The aim of our study was to determine the structure of plant communities and to evaluate the succession changes of meadow plant species on the Natura 2000 site located in a drained valley within the context of the achievement of the favourable status of preservation.

\section{Material and Methods}

The research area is located in the peaty valley of the Mala River in central Poland, $20 \mathrm{~km}$ south of Warsaw (Fig. 1). Until 1941 it was the terrain's depression on peat substrates grown mostly by Carex acutiformis community. The Mala River regulation works were performed in the years 1941-1943. The draining, amelioration works (1968-1971), and full cultivation allowed the introduction of fodder varieties of plants and established the productive meadows for milking cattle feeding. On the southern part of the area (coverage of $81 \mathrm{ha}$ ), the mixtures of two meadow plant species' seeds were sown. The following species were seeded on the larger part: Festuca pratensis, Festuca rubra, Phleum pratense, Dactylis glomerata, Poa pratensis, Agrostis giganthea, Alopecurus pratensis, Lolium multiflorum, Lotus corniculatus, and Trifolium hybrydum. The species sown in drier places were as follows: Arrhenatherum elatius, Lolium perenne, Trifolium pratensis, and Medicago lupulina [22]. The intensive use for fodder production by cooperative
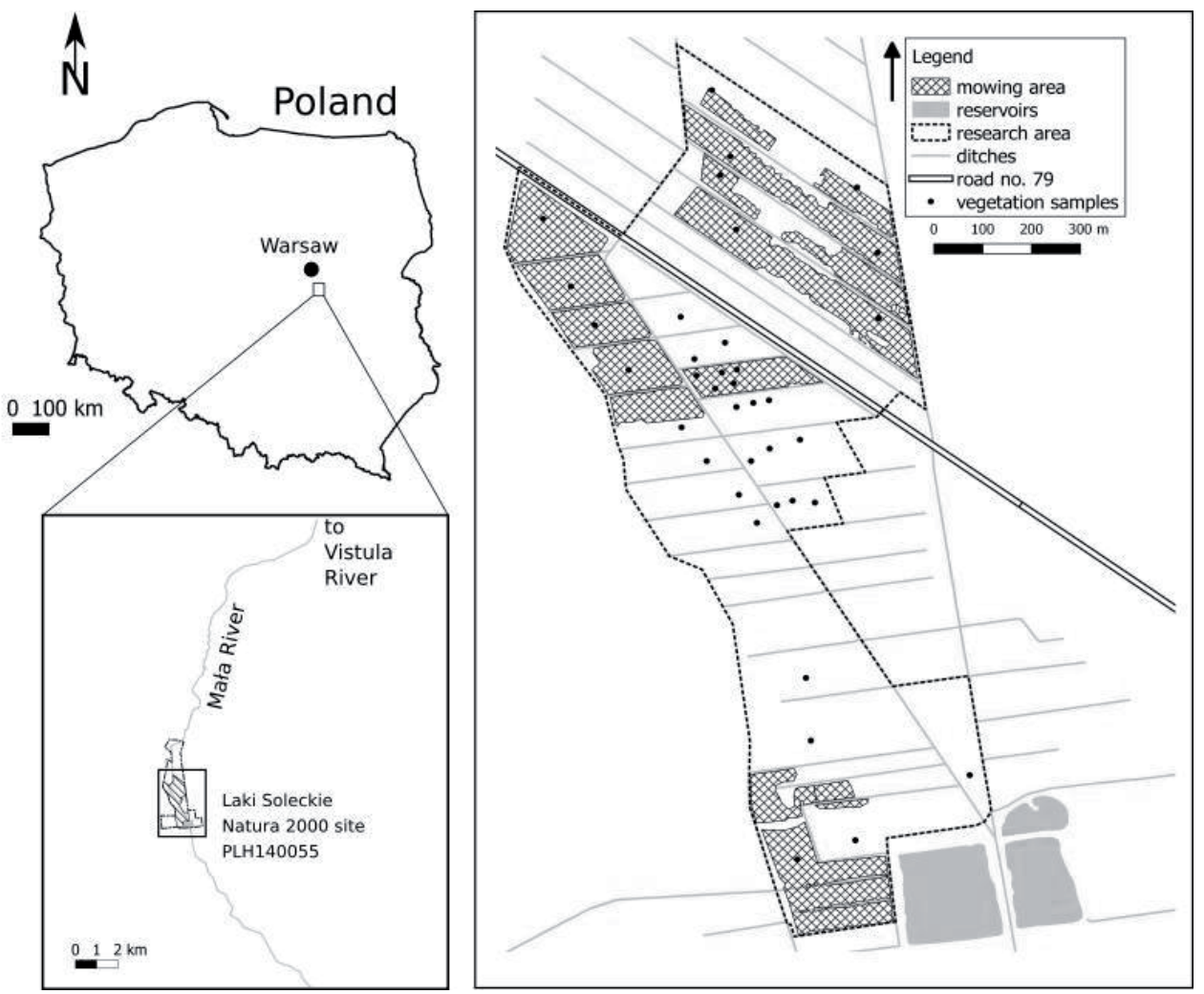

Fig. 1. Location of vegetation sampling points. 
Table 1. Weather conditions in growing seasons 2014-2015 (meteorological station Ursynow-Warsaw).

\begin{tabular}{|c|c|c|c|c|c|c|c|}
\hline \multirow{2}{*}{ Year } & \multicolumn{6}{|c|}{ Month } & \multirow{2}{*}{$\frac{\text { Growing season }}{\text { IV-IX }}$} \\
\hline & IV & $\mathrm{V}$ & VI & VII & VIII & IX & \\
\hline \multicolumn{8}{|c|}{ Mean temperature $\left[{ }^{\circ} \mathrm{C}\right]$} \\
\hline 2014 & 10.5 & 14.4 & 16.3 & 21.1 & 18.3 & 15.0 & 16.0 \\
\hline 2015 & 9.1 & 13.7 & 18.1 & 20.5 & 23.0 & 15.6 & 16.7 \\
\hline \multicolumn{8}{|c|}{ Sum of precipitation $[\mathrm{mm}]$} \\
\hline 2014 & 63.9 & 80.6 & 63.8 & 100.1 & 70.8 & 7.0 & 386.2 \\
\hline 2015 & 31.4 & 57.7 & 37.5 & 66.2 & 11.3 & 73.1 & 277.2 \\
\hline \multicolumn{5}{|c|}{ Characteristics of growing seasons } & \multicolumn{3}{|c|}{ Hydrothermic index of Vinczeffy $\left[\Sigma \mathrm{mm} \cdot \sum^{\circ} \mathrm{C}^{-1}\right]$} \\
\hline 2014 & \multicolumn{4}{|c|}{ Dry } & \multicolumn{3}{|c|}{0.132} \\
\hline 2015 & \multicolumn{4}{|c|}{ Extremely dry } & \multicolumn{3}{|c|}{0.091} \\
\hline
\end{tabular}

and state farms lasted until the beginning of political and economic transformation in the 1990s. The intensive fodder production on such objects became unprofitable for many reasons. The most important was the localition within the zone of expanded Warsaw agglomeration and falling competitiveness of traditional agricultural production. In 2009 the Special Area of Habitats Protection was approved as a Natura 2000 site: Laki Soleckie PLH140055 (5202’05N, 21066’03E).

The plant community of code 6510 lowland hay meadows was the topic of our investigation. The studies were carried out in 2014-2015. They covered the analysis of literature, archival, and cartographic documentation of the area plus our own field surveys focusing on the botanical composition of meadows' sward in 56 sites (Fig. 1). Vegetation samples from an area $1 \times 1 \mathrm{~m}$ cut to a height of $5 \mathrm{~cm}$ were dried under the roof. They were weighted in the laboratory, and each sample was divided for the separated species. The onespecies samples were weighed to determine their share of total mass.

The list of species found in the samples was compared with the checklist of meadow community types used for natural habitat monitoring [11] and with the list of species sown during the melioration works. That allowed us to indicate the representative species for lowland hay meadow communities in order to determine the share of particular meadow plant groups and native, alien (invasive), or expansive species. On the base of botanical composition, the floristic types were determined by taking the name from the species occurring with a share of more than $20 \%$ of the community.

The species composition and abundance of particular species were determined in five presence classes according to the phytosociological scale, as I - the species occurs sporadically in $0.1-20 \%$ of samples; II not very frequent in $20.1-40 \%$; III - medium frequent in $40.1-60 \%$; IV - frequent in $60.1-80 \%$; and $\mathrm{V}$ - constant in $80.1-100 \%$.
On the base of the orthophotomaps, aerial photographs, and the data obtained from the Regional Directorate of Environmental Protection in Warsaw and field surveys, the following changes in landscape were determined: 1) the area of lowland hay meadows 6510 in $2008-2014 ; 2$ ) the area covered by trees and shrubs in 1997-2014; and 3) land use in 1997-2014.

Floristic diversity was determined with the help of the Shannon-Wiener (H') index. The utility value was estimated according to the fodder value score (FVS) with Filipek's method (modified Klapp's method), where particular species with its utility number (in scale from -3 to 10 ) is multiplied by its share in sward and further summarized $[23,24]$. The utility value of the sward is classified into four categories: very good (FVS 8,1-10,0), good (FVS 6,1-8,0), mediocre (FVS 3,1-6,0), and poor $(\mathrm{FVS}<3,0)$. The statistical calculations were performed with the software package STATISTICA 13 . The significance of differences between means of particular functional plant groups was analyzed by using the oneway ANOVA model complemented by the Fischer test $(\mathrm{P}<0.05)$ as post-hoc.

The weather conditions in the research period were not favourable for growth and development of meadow species (Table 1). The climatic indicator of the precipitation for growing season 2014 showed drought, and catastrophic drought for the 2015 growing season.

\section{Results and Discussion}

An analysis of vegetation samples has showed the occurrence of 88 plants species, including 21 grasses, 5 sedges, 3 rushes, 4 legumes, and 55 other forbs (Table 2). The average number of species per $1 \mathrm{~m}^{2}$ varied from 14 to 21 (Table 2). Holcus lanatus, Poa pratensis, Alopecurus pratensis, Deschampsia caespitosa, and Festuca rubra were the species from a monocotyledonous class that most frequently appeared (IV) in the sward. In that group of plants only Poa pratensis and Festuca rubra are the species 
Table 2. List of species, the share of species in hay yields (A), species abundance (S), mean number and range of species per $1 \mathrm{~m}^{2}$ of the Laki Soleckie communities on various types of agricultural management.

\begin{tabular}{|c|c|c|c|c|c|c|c|c|c|}
\hline \multirow[t]{2}{*}{ Group and species } & \multicolumn{2}{|c|}{ Early mown } & \multicolumn{2}{|c|}{ Late mown } & \multicolumn{2}{|c|}{$\begin{array}{c}\text { Sporadically } \\
\text { mown }\end{array}$} & \multicolumn{2}{|c|}{ Unmown } & \multirow{2}{*}{$\begin{array}{c}\text { Abundance } \\
\text { in all sam- } \\
\text { ples }\end{array}$} \\
\hline & A & S & A & $\mathrm{S}$ & A & $\mathrm{S}$ & A & $\mathrm{S}$ & \\
\hline \multicolumn{10}{|c|}{ Grasses: } \\
\hline Agrostis gigantea Roth & - & - & - & - & - & - & 0.03 & I & I \\
\hline Alopecuru spratensis L. & 12.35 & IV & 1.78 & III & 5.91 & III & 12.53 & IV & IV \\
\hline Anthoxanthum odoratum L. & 1.36 & II & 1.99 & IV & 0.29 & II & 0.71 & II & III \\
\hline Arrhenatherum elatius (L.) P. Beauv. * & 11.82 & IV & 0.14 & II & 10.79 & III & 11.02 & II & III \\
\hline Avenula pubescens (Huds.) Dumort. & 5.02 & III & 0.67 & I & 1.10 & II & 0.21 & I & II \\
\hline Bromus erectus Huds. & - & - & - & - & - & - & 0.04 & I & I \\
\hline Bromus inermis Ley ss. & 7.45 & III & - & - & - & - & 4.26 & II & II \\
\hline Dactylis glomerata L. & 0.50 & II & 0.00 & I & - & - & 0.11 & I & I \\
\hline Deschampsia caespitosa (L.) P. Beauv.** & 1.63 & II & 21.04 & $\mathrm{~V}$ & 11.25 & IV & 8.63 & III & IV \\
\hline Elymus repens (L.) Gould** & 2.15 & III & 0.14 & I & 8.26 & II & 10.28 & III & II \\
\hline Festuca arundinacea Schreb. & 0.47 & I & - & - & - & - & - & - & I \\
\hline Festuca pratensis Huds. & - & - & 5.27 & III & 0.34 & I & 0.00 & I & I \\
\hline Festuca rubra L. s. s.* & 6.21 & IV & 10.08 & IV & 10.20 & IV & 4.43 & II & IV \\
\hline Glyceria fluitans (L.) R. Br. & - & - & - & - & 2.83 & I & - & - & I \\
\hline Holcus lanatus L. & 14.95 & $\mathrm{~V}$ & 28.46 & $\mathrm{~V}$ & 4.00 & IV & 8.92 & III & IV \\
\hline Phalaris arundinacea $\mathrm{L}$. & 7.20 & I & - & - & 2.35 & II & 0.18 & I & I \\
\hline Phalaris arundinacea $\mathrm{L}$. & - & - & 0.39 & I & - & - & 0.10 & I & I \\
\hline Phragmites australis (Cav.) Trin.** & - & - & - & - & 0.02 & I & 0.29 & I & I \\
\hline Poa palustris L. & - & - & 0.00 & I & 0.00 & I & 0.51 & III & I \\
\hline Poa pratensis L.* & 0.84 & $\mathrm{~V}$ & 1.54 & III & 1.46 & IV & 5.03 & $\mathrm{~V}$ & IV \\
\hline Poa trivialis $\mathrm{L}$. & 0.12 & III & 5.41 & $\mathrm{~V}$ & 3.80 & III & 2.66 & II & III \\
\hline \multicolumn{10}{|c|}{ Sedges } \\
\hline Carex gracilis Curtis & 13.31 & IV & - & - & 13.41 & III & 4.70 & II & II \\
\hline Carex hirta L. & 0.03 & II & 0.36 & III & 0.18 & II & 0.03 & I & II \\
\hline Carex leporine $\mathrm{L}$. & 0.93 & II & 0.00 & I & - & - & 0.02 & I & I \\
\hline Carex nigra Reichard & - & - & - & - & - & - & 0.02 & I & I \\
\hline Carex vesicaria $\mathrm{L}$. & - & - & - & - & 3.37 & I & - & - & I \\
\hline \multicolumn{10}{|c|}{ Rushes } \\
\hline Juncus articulates L. em. K. Richt. & 0.02 & II & 0.04 & II & 0.01 & I & 0.01 & I & I \\
\hline Juncus conglomeratus L. em. Leers & 1.02 & II & - & - & 2.46 & I & 0.45 & I & I \\
\hline Juncus effusus L. & - & - & 1.06 & I & - & - & 0.18 & I & I \\
\hline \multicolumn{10}{|c|}{ Legumes } \\
\hline Lathyrus pratensis L. & 1.15 & IV & 0.02 & II & 1.10 & IV & 0.24 & III & III \\
\hline Lotus corniculatus L. & 0.09 & II & 0.36 & I & - & - & - & - & I \\
\hline Trifolium dubium Sibth. & 0.01 & I & - & - & - & - & - & - & I \\
\hline Vicia cracca $\mathrm{L}$. & 0.42 & IV & 0.02 & I & 0.32 & II & 0.10 & III & II \\
\hline
\end{tabular}


Table 2. Continued.

\begin{tabular}{|c|c|c|c|c|c|c|c|c|c|}
\hline \multicolumn{10}{|c|}{ Forbs } \\
\hline Achillea millefolium $\mathrm{L}$. & 0.20 & III & 0.00 & I & 0.37 & II & 0.04 & II & II \\
\hline Aegopodium podagraria $\mathrm{L}$. & - & - & - & - & - & - & 0.01 & I & I \\
\hline Allium oleraceum L. & 0.03 & I & - & - & - & - & - & - & I \\
\hline Allium rotundum $\mathrm{L}$. & 0.06 & I & - & - & - & - & - & - & I \\
\hline Cardaminopsis arenosa (L.) Hayek & 0.05 & II & 0.01 & I & 0.28 & II & 0.04 & I & II \\
\hline Centaurea jacea $\mathrm{L}$. & - & - & - & - & - & - & 0.04 & I & I \\
\hline Cerastium holosteoides Fr. em. Hyl. & 0.04 & II & 0.07 & III & 0.00 & I & 0.01 & I & II \\
\hline Cirsium arvense (L.) Scop.** & 0.02 & I & - & - & 0.17 & I & 1.29 & II & I \\
\hline Cirsium canum (L.) All. & - & - & - & - & 0.05 & I & 0.36 & I & I \\
\hline Cirsium palustre (L.) Scop. & - & - & 0.05 & I & 0.00 & I & 0.00 & I & I \\
\hline Cnidium dubium (Schkuhr) Thell. & - & - & - & - & - & - & 0.00 & $\mathrm{I}$ & $\mathrm{I}$ \\
\hline Daucus carota $\mathrm{L}$. & 0.29 & I & - & - & - & - & - & - & I \\
\hline Epilobium palustre $\mathrm{L}$. & - & - & - & - & - & - & 0.03 & $\mathrm{I}$ & $\mathrm{I}$ \\
\hline Equisetum palustre $\mathrm{L}$. & 0.01 & II & 2.13 & IV & 0.69 & II & 0.51 & II & II \\
\hline Filipendula ulmaria (L.) Maxim. & 0.27 & II & 0.15 & I & 0.00 & $\mathrm{I}$ & 0.03 & $\mathrm{I}$ & $\mathrm{I}$ \\
\hline Galeopsis tetrahit $\mathrm{L}$. & - & - & 0.00 & I & 0.48 & III & 0.49 & II & II \\
\hline Galium aparine L.** & 0.02 & II & 0.12 & I & 0.13 & II & 0.64 & III & II \\
\hline Galium boreale L. & - & - & - & - & - & - & 0.00 & $\mathrm{I}$ & $\mathrm{I}$ \\
\hline Galium mollugo L.* & 0.01 & I & - & - & 0.05 & I & 0.77 & II & $\mathrm{I}$ \\
\hline Galium palustreL. & 0.03 & II & 0.40 & IV & 1.73 & III & 0.02 & $\mathrm{I}$ & III \\
\hline Galium verum $\mathrm{L}$. & 0.04 & I & - & - & 0.04 & $\mathrm{I}$ & - & - & $\mathrm{I}$ \\
\hline Geum rivale $\mathrm{L}$. & - & - & - & - & 0.00 & $\mathrm{I}$ & - & - & $\mathrm{I}$ \\
\hline Glechoma hederacea L. & 0.01 & I & - & - & - & - & 0.04 & $\mathrm{I}$ & $\mathrm{I}$ \\
\hline Helichrysum arenarium (L.) Moench & - & - & - & - & - & - & 0.02 & $\mathrm{I}$ & $\mathrm{I}$ \\
\hline Heracleum sphondylium L. & 0.05 & I & - & - & 0.04 & $\mathrm{I}$ & 0.05 & $\mathrm{I}$ & $\mathrm{I}$ \\
\hline Hypericum perforatum $\mathrm{L}$. & - & - & - & - & - & - & 0.02 & $\mathrm{I}$ & $\mathrm{I}$ \\
\hline Linaria vulgaris Mill. & 0.09 & II & - & - & 0.03 & $\mathrm{I}$ & 0.39 & II & $\mathrm{I}$ \\
\hline Linum catharticum $\mathrm{L}$. & - & - & 0.00 & I & - & - & - & - & $\mathrm{I}$ \\
\hline Luzula campestris (L.) DC. & 0.10 & II & 0.06 & I & - & - & - & - & $\mathrm{I}$ \\
\hline Lychnis flos-cuculi L. & 1.94 & III & 0.41 & IV & 0.09 & $\mathrm{I}$ & 0.03 & $\mathrm{I}$ & II \\
\hline Lythrum salicaria $\mathrm{L}$. & - & - & 0.13 & I & 0.05 & $\mathrm{I}$ & 0.53 & $\mathrm{I}$ & $\mathrm{I}$ \\
\hline Melandrium album (Mill.) Garcke & 0.06 & I & - & - & - & - & 0.04 & $\mathrm{I}$ & $\mathrm{I}$ \\
\hline Plantago lanceolata L. & 3.88 & III & 2.87 & III & 0.85 & II & 0.20 & II & II \\
\hline Polygonum bistorta L. & 0.07 & I & - & - & 0.01 & $\mathrm{I}$ & 0.24 & $\mathrm{I}$ & $\mathrm{I}$ \\
\hline Polygonum hydropiper L. & 0.04 & $\mathrm{I}$ & - & - & 0.45 & $\mathrm{I}$ & 0.44 & $\mathrm{I}$ & $\mathrm{I}$ \\
\hline Polygonum persicaria L. & - & - & - & - & - & - & 0.26 & $\mathrm{I}$ & $\mathrm{I}$ \\
\hline Potentilla anserina $\mathrm{L}$. & - & - & 0.04 & $\mathrm{I}$ & - & - & - & - & $\mathrm{I}$ \\
\hline Potentilla argentea L. s. s. & 0.15 & II & 0.35 & II & 0.43 & I & 0.20 & $\mathrm{I}$ & I \\
\hline Ranunculus acris L. s. s. & 0.06 & II & 0.20 & III & 0.11 & I & 0.98 & I & II \\
\hline
\end{tabular}


Table 2. Continued.

\begin{tabular}{|c|c|c|c|c|c|c|c|c|c|}
\hline Ranunculus auricomus L. s. 1. & 0.02 & I & 0.09 & I & 0.00 & I & 0.00 & I & I \\
\hline Ranunculus reptans $\mathrm{L}$. & 0.76 & II & 3.64 & $\mathrm{~V}$ & 4.34 & III & 4.00 & III & IV \\
\hline Rumex acetosa $\mathrm{L}$. & 0.82 & IV & 1.54 & IV & 0.16 & II & 0.65 & III & III \\
\hline Sanguisorba officinalis L. & - & - & - & - & - & - & 0.09 & I & I \\
\hline Selinum carvifolia (L.) L. & 0.10 & I & - & - & - & - & - & - & I \\
\hline Solidago canadensis L.*** & - & - & - & - & - & - & 2.65 & I & I \\
\hline Solidago gigantea Aiton*** & - & - & - & - & - & - & 0.07 & I & I \\
\hline Stellaria graminea $\mathrm{L}$. & 0.29 & III & 0.05 & I & 0.02 & I & 0.25 & II & II \\
\hline Stellaria media (L.) Vill. & 0.01 & I & - & - & - & - & - & - & I \\
\hline Symphytum officinale L. & - & - & - & - & 0.04 & I & - & - & I \\
\hline Taraxacum officinale F. H. Wigg. & 0.02 & II & - & - & 0.03 & I & 0.00 & I & I \\
\hline Tragopogon pratensis L. s. s.* & 0.68 & I & - & - & - & - & - & - & I \\
\hline Urtica dioica L.** & 0.13 & I & 2.22 & II & 2.24 & III & 6.95 & IV & II \\
\hline Urtica urens $\mathrm{L}$. & - & - & - & - & - & - & 0.00 & I & I \\
\hline Veronica chamaedrys $\mathrm{L}$. & 0.60 & IV & 1.41 & IV & 1.06 & III & 0.93 & II & III \\
\hline Veronica longifolia $\mathrm{L}$. & - & - & 5.29 & II & 2.61 & I & 1.00 & I & I \\
\hline Mean number and range of species per $1 \mathrm{~m}^{2}$ & \multicolumn{2}{|c|}{$21(13-30)$} & \multicolumn{2}{|c|}{$16(9-25)$} & \multicolumn{2}{|c|}{$15(10-20)$} & \multicolumn{2}{|c|}{$14(8-21)$} & \\
\hline
\end{tabular}

Values with different letters are significantly different $(\mathrm{P}<0.05)$. Names of invasive species marked by ***, expansive species by ** and representative species by*.

representative for the natural habitat 6510 - subtype 6510-2 - Poa-Fastucetum rubrae that occurs in habitats of poorer nutrient contents. The numerous occurrences of Holcus lanatus and Deschampsia caespitosa may indicate the worsening of humid conditions of the habitat [25]. This could be caused by weather conditions, especially the drought in 2015. From the large group of forbs, Ranunculus repens shows the highest abundance (IV) as a no-representative species for lowland hay meadows but only as the accompanying one for subtype 6510-2. Lathyrus pratensis, Poa trivialis, Rumex acetosa, and Anthoxanthum odoratum occurred with relatively high abundance (III) on the analysed area. The occurrence frequency of Arrhenatherum elatius and Galium palustre, representative for subtype $6510-1$, amounted to about $42 \%$. Sporadic species were the majority of the ones (58) found in the sward of studied meadow communities. Most of them (42) were dicotyledonous species. Only one of them, Tragopogon pratensis, is the representative species for habitat 6510 . Sporadically occurring species from monocotyledonous plants were the tall, highly productive fodder grasses. From 14 species seeded during after melioration works, 10 were found in vegetation samples. These were as follows: Festuca pratensis, Festuca rubra, Phleum pratense, Alopecurus pratensis, Dactylis glomerata, Poa pratensis, Agrostis giganthea, Alopecurus pratensis, Arrhenatherum elatius, and Lotus corniculatus. Three of them had a little bigger share (about $8 \%$ ) in the sward and frequent occurrence (IV), these were Arrhenatherum elatius, Alopecurus pratensis, and Festuca rubra. The share of the rest of the species amounted to averages from 0.1 to $2.2 \%$. Amongst them, Poa pratensis occurred most frequently (IV).

The field surveys allowed us to distinguish four types of management in the research area: early mown areas between June and July, late mown between July and August with biomass decreasing, and sporadically mown once in 3-4 years and unmown for at least 5 years.

The analysis of the species composition of the communities and the occurrence of the species representative for natural habitat 6510 in dependence on the meadow management showed that most plant species (71) occurred on the meadows that had not been mown for at least 5 years. However, the Shannon-Wiener index showed their lowest floristic diversity and lowest mean number of species found on that unmanaged terrains amounted to 14 in one vegetation sample $\left(1 \mathrm{~m}^{2}\right)$ (Table 3). Many studies in Central and Northern Europe have revealed a decline in species diversity (richness) when ecological succession is beginning [26-28] and it also has been stated in this study. Some of the researchers noted no difference in species richness between permanently managed and abandoned meadows [29, 30].

On unmown areas, tall grasses had the largest share in the sward mass (about 47\%) (Table 3). There were 
Table 3. Percentages of particular plant groups in sward yield, total number of species, Shannon-Weiner index H', and fodder value score FVS of the investigated meadow communitie.

\begin{tabular}{|c|c|c|c|c|}
\hline Plant group & Early mown & Late mown & Sporadically mown & Unmown \\
\hline Grasses: & $72.09^{\mathrm{a}}$ & $76.87^{\mathrm{b}}$ & $62.60^{\mathrm{ab}}$ & $69.95^{\mathrm{a}}$ \\
\hline - high: & $43.57^{\mathrm{a}}$ & $28.75^{\mathrm{b}}$ & $41.74^{\mathrm{ab}}$ & $47,43^{\mathrm{a}}$ \\
\hline - medium high: & $20.11^{\mathrm{a}}$ & $34.52^{\mathrm{b}}$ & $8.91^{\mathrm{a}}$ & $12.37^{\mathrm{a}}$ \\
\hline - low: & $8.41^{\mathrm{a}}$ & $13.60^{\mathrm{a}}$ & $11.95^{\mathrm{a}}$ & $10.17^{\mathrm{a}}$ \\
\hline Sedges: & $14.27^{\mathrm{ab}}$ & $0.37^{\mathrm{a}}$ & $16.95^{\mathrm{b}}$ & $4.77^{\mathrm{ab}}$ \\
\hline Rushes: & $1.04^{\mathrm{a}}$ & $1.10^{\mathrm{a}}$ & $2.47^{\mathrm{a}}$ & $0.64^{\mathrm{a}}$ \\
\hline Legumes: & $1.67^{\mathrm{a}}$ & $0.39^{\mathrm{ab}}$ & $1.42^{\mathrm{ab}}$ & $0.34^{\mathrm{b}}$ \\
\hline Forbs: $^{\mathrm{b}}$ & $10.94^{\mathrm{a}}$ & $21.26^{\mathrm{a}}$ & $16.56^{\mathrm{a}}$ & $24.30^{\mathrm{a}}$ \\
\hline $\begin{array}{c}\text { Total number of species } \\
\left(\text { LSD }_{0,05}: 3\right)\end{array}$ & $57^{\mathrm{a}}$ & $45^{\mathrm{b}}$ & $54^{\mathrm{a}}$ & $71^{\mathrm{c}}$ \\
\hline $\begin{array}{c}\text { Shannon-Weiner index H' } \\
\left(\text { LSD }_{0,05}: 0.23\right)\end{array}$ & $1.69^{\mathrm{a}}$ & $1.74^{\mathrm{a}}$ & $1.59^{\mathrm{ab}}$ & $1.43^{\mathrm{b}}$ \\
\hline $\begin{array}{c}\text { Fodder value score FVS } \\
\left(\text { LSD }_{0,05}: 1.50\right)\end{array}$ & $6.08^{\mathrm{a}}$ & $3.66^{\mathrm{b}}$ & $4.68^{\mathrm{ab}}$ & $4.64^{\mathrm{ab}}$ \\
\hline
\end{tabular}

Values with different letters are significantly different $(\mathrm{P}<0.05)$

mostly: Alopecurus pratensis, Arrhenatherum elatius, and expansive native species Elymus repens. The abundance of the representative species Arrhenatherum elatius was low, but $A$. pratensis and $A$. repens were much higher. The relatively large occurrence frequency (III) and the share in sward (about 8\%) were shown there by Deschampsia caespitosa and Holcus lanatus, the species undesirable from the economic as well as the natural point of view. Those species have a very low nutritional value and are fast spreading, which could lower floristic diversity and contribute to decreasing the meadows' fodder value. The numerous presence of Holcus lanatus may be the result of the occurrence of muck soils with variable moisture and excessive nitrogen fertilization [11], although it had not been reported in the surveyed area. Some researchers claim that a large share of Deschampsia caespitosa, Alopecurus pratensis, Holcus lanatus, and Anthoxanthum odoratum can indicate the degradation of the communities of lowland hay meadows as a result of habitat drying, especially abandonment of mowing [11, 31, 32]. The distinguishing feature of this community is also a large number and share of dicotyledonous plants from a group of forbs (Table 3). Most of them are sporadic species of the small share in the biomass. However, invasive species from the genus Solidago appear among them, which is particularly disadvantageous for lowland hay meadow community preservation.

Late mowed plant communities had the lowest number of species (45) in sward biomass, but the highest value of Shannon-Wiener index (1.74). Holcus lanatus, Deschampsia caespitosa, Poa trivialis, and Ranunculus repens were noted in all vegetation samples of this group. Among surveyed communities, only that one had such a large share of $H$. lanatus $(28 \%)$ and D. caespitosa $(21 \%)$. The fast spread of these plants decreased floristic diversity and caused the occurrence of just one representative species for that natural habitat Arrhenatherum elatius, with its low (about 2\%) weight share. The numerous occurrences of such dicotyledonous plants as Veronica longifolium and Urtica dioica was stated, which is in connection with grasses such as Poa trivialis showing the shrubby direction of the plant succession and also give low fodder value score of the sward (FVS 3.66).

The rest of the meadow communities had similar over 50 species - sward and a similar share of particular plant groups (Table 3). However, detailed vegetation analysis of the surface of $1 \mathrm{~m}^{2}$ shows that early mown communities had a larger number of species and number of representative species (about $40 \%$ higher) (3), especially Tragopogon pratensis. The presence of these species was found only in this manner of management. These communities also had a relatively high floristic diversity index (H' 1.69) and good fodder value score (FVS 6.08).

Two floristic types representative for lowland hay meadows 6510 - Arrhenatherum elatius and Festuca rubra - occurred most frequently on early mown meadows. The communities with the domination of Holcus lanatus and Alopecurus pratensis occurred just locally. On the late mown meadows, sporadically mown meadows and unmown ones the following communities were dominated by Deschampsia caespitosa and Elymus repens floristic types. The floristic types with expansive nitrophilous species Urtica dioica and invasive alien species Solidago canadensis and Solidago gigantea occurred only on unmown areas. Some researchers 


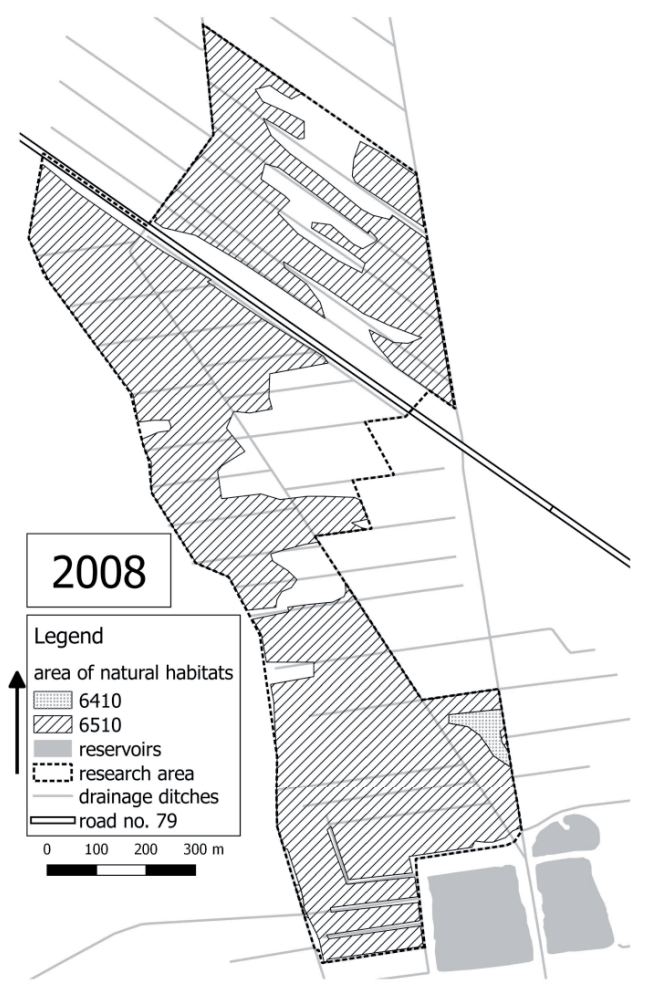

Fig. 2. Lowland hay meadow 6510 areas in years 2008 and 2014

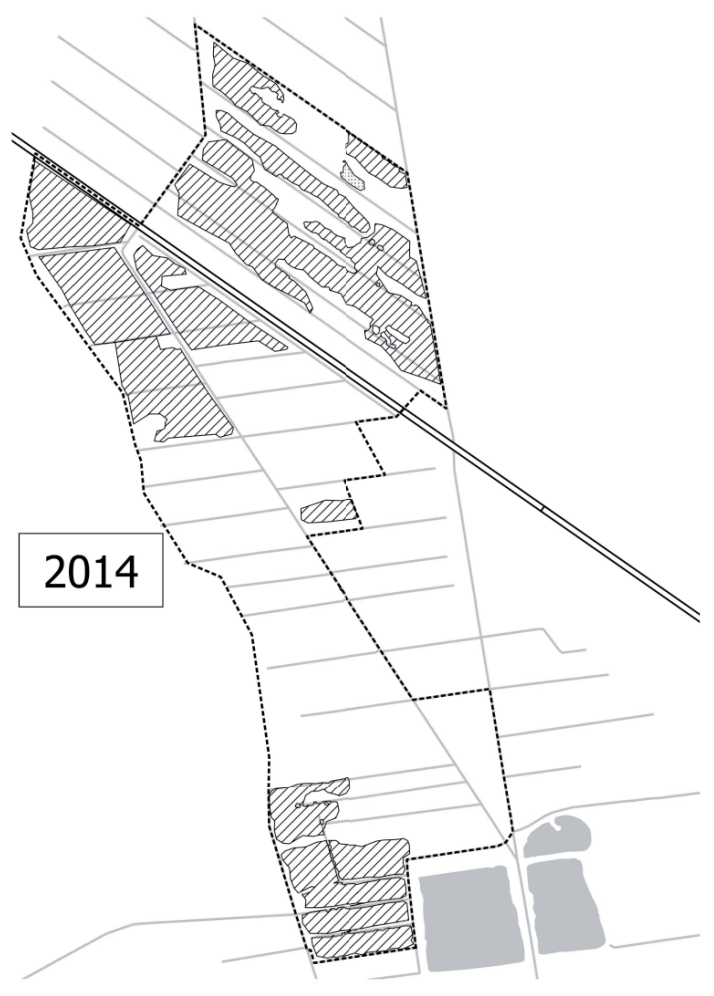

claim that a gradual increase of nitrophilous plants share appears with the abandonment of management [19, 33, 34], which is seen in the case of the results of Urtica dioica shared in the research area. This species increases in its number and abundance along with decreasing intensity and cessation of pratotechnical treatments. This may be caused by remaining necromass as the result of improper management as well as abandonment. An increasing role of an invasive species Deschampsia caespitosa on lowland hay meadows 6510 mainly on late mown and sporadically mown areas may be related to the presence of periodically wet or swampy habitats and improper agricultural management [19].

On dewatered terrain the cessation of agricultural use diminishes care about existing amelioration infrastructure [35], which leads to changes of moisture conditions in drying or swamping direction [36]. Drying on marshy soils leads to fast mineralization of organic matter, nitrogen release, and encroachment of nitrophilous plants $[33,34,37]$. Swamping leads to the occurrence of hydrophilic plants, which is the more advantageous process and could create more valuable wetland or swamp natural habitats in the future. For that reason, lowland hay meadow natural habitats 6510 are protected also beyond Natura 2000 areas [38].

The area of natural habitats lowland hay meadows 6510 on Laki Soleckie decreased in $24.4 \%$ (54.2 ha) in the period 2008-2014. In the southern part, where the study was conducted, the area of natural habitats (59.4 ha) decreased in 32.1 ha $[39,40]$, which points to a $40 \%$ loss (Fig. 2). Moreover, the area taken by trees and shrubs increased 57\% (from 6.2 to 14.6 ha) in 1997-2014. At the same time, the systematically mowed area decreased from $59 \%$ to $33 \%$ (Fig. 3). The biggest loss of natural habitat $6510(88 \%)$ was noticed on unmown terrain for at least 5 years. Significant lowland hay meadows 6510 area loss, consisted for over 6 years, shows fast-progressing secondary succession on the part of the area. The botanical separation analysis shows that mowing delay or sporadic mowing rapidly leads to significant changes in the species composition, which further leads to a decrease in fodder value and its use in animal feed. Even horses in the nearby stud farm are fed with industrial feed, which causes cessation of mowing and irreversible changes in the floristic composition and vanishing of the natural habitat 6510 .

The abandonment of extensive traditional farming practices is the most common problem of agricultural land habitats of community interest preservation across the entire UE [5]. Generally, it is caused by a combination of political, environmental, economic, and social factors. In the case of particular unique site factors, for example ageing rural populations, and constraints posed by organic soil properties undermine the viability of farming. The CAP "greening" in current perspective (2014-2020) gives a chance to develop results-based agri-environment payment schemes across the EU, allowing farmers the flexibility to choose the most appropriate management for biodiversity delivery on farmland in Europe [41]. 


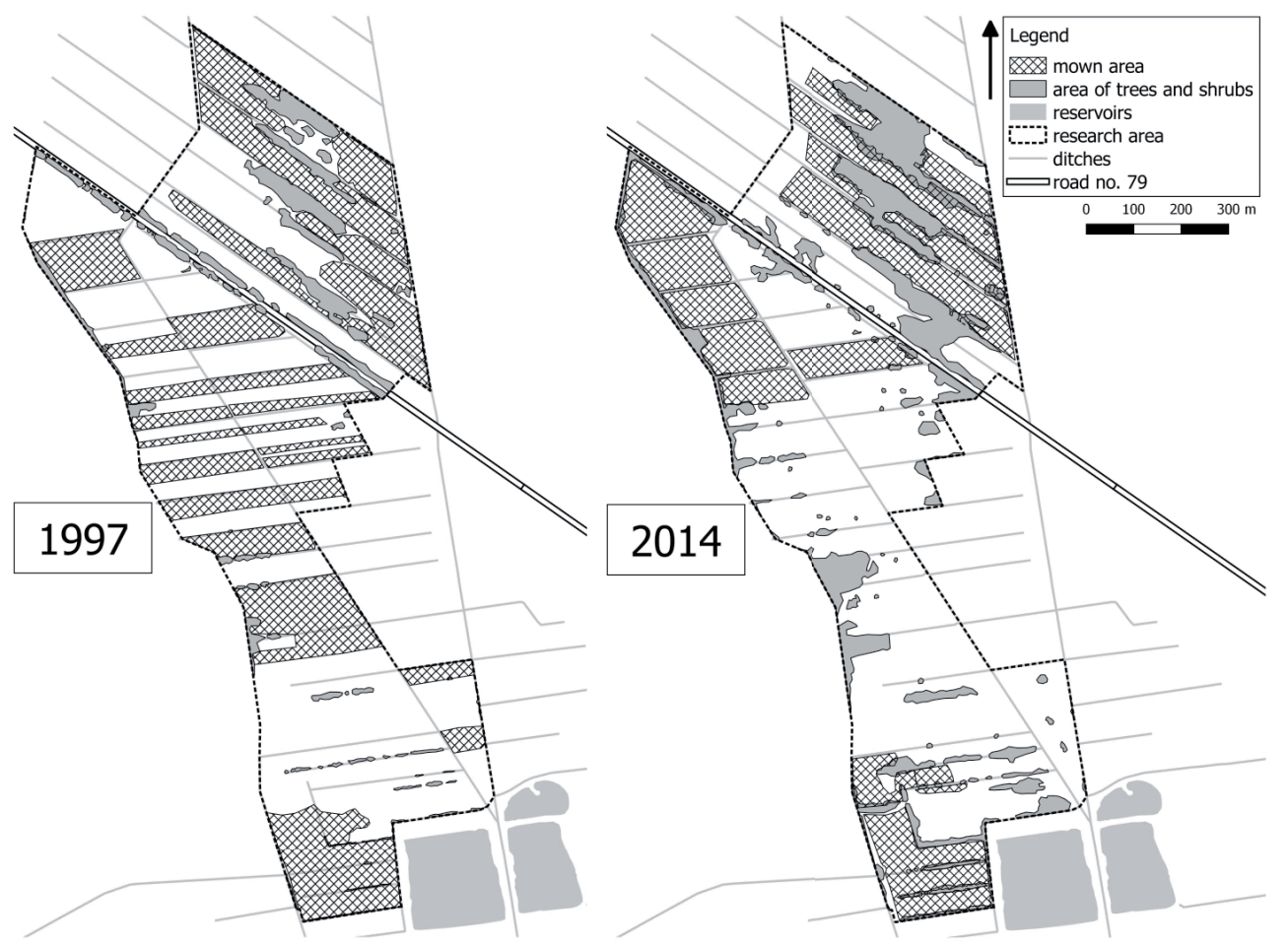

Fig. 3. Mown areas and areas of woods and shrubs in years 1997 and 2014.

\section{Conclusions}

Two representative floristic types for lowland hay meadows 6510 - Arrhenatherum elatius and Festuca rubra occurred most frequently on early mown meadows. The communities with the domination of Holcus lanatus and Alopecurus pratensis occurred locally. The mowing delay or sporadic mowing lead rapidly to significant changes in species composition. The late mown and sporadically mown meadows were dominated by Deschampsia caespitosa and Elymus repens floristic types. The floristic types with expansive species Urtica dioica and alien species Solidago canadensis and Solidago gigantea occurred only on unmown areas.

The agricultural value of lowland hay meadows natural habitats 6510 on Natura 2000 Laki Soleckie PLH 140055 area is generally low. Mowing delay or sporadic mowing lead to a decrease in fodder value and its use in animal feed. On dewatered terrain the cessation of agricultural use diminished care of existing amelioration infrastructure, which leads to drying or swamping. Drying of marshy soils leads to fast mineralization carbon dioxide of nitrogen release, encroachment of nitrophilous plants, and the disappearance of peat earth layer. The swamping leads to the occurrence of hydrophilic plants, and could create more valuable wetland or swamp natural habitats in the future.
The area of habitat 6510 has decreased by $24.4 \%$ in the period 2008-2014. On the southern part of the investigated area the share of that habitat has shrunk from 59.4 ha to 27.3 ha and a $57 \%$ increase in woody vegetation cover. It shows that the rates of payments in the framework of the Common Agricultural Plan (CAP) for agricultural practices favourable for keeping or improving the status of natural sites 6510 were not efficient.

The effective maintenance of favourable status of natural habitat requires the better form of payments allowing a farmer the flexibility to choose the most appropriate management to achieve that result. The CAP "greening" in current perspective (2014-2020) gives a chance of the development of results-based agrienvironment payment schemes across the EU, allowing farmers flexibility in choosing the most appropriate management to increase biodiversity in farmlands. The payment rates proposed in the Rural Development Programme for sustaining and restoring of the conservation status of natural habitats in Laki Soleckie should also focus on keeping the proper moisture of organic soil and covering the costs of modernization of the amelioration system indispensable for better water management.

\section{Conflict of Interest}

The author declares no conflict of interest. 


\section{References}

1. EUROPEAN UNION. The EU Biodiveristy Strategy to 2020. Luxembourg: Publications Office of the European Union. 2011.

2. GRODZIŃSKA-JURCZAK M., STRZELECKA M. Effectiveness of Nature Conservation - A Case of Natura 2000 Sites in Poland. Protected Area Management, 183, 2012.

3. EUROPEAN COMMISSION ENVIRONMENT. The State of Nature in the EU. Reporting under the EU Habitats and Birds Directives 2007-2012. Luxembourg. 2015.

4. KARMENU VELLA. Natura 2000. The Action Plan: for nature, people and the economy. Nature and Biodiversity Newsletter. 2017.

5. EUROPEAN COMMISSION. Farming for Natura 2000. 2014.

6. HABEL J.C., DENGLER J., JANIŠOVÁ M., TÖRÖK P., WELLSTEIN C., WIEZIK M. European grassland ecosystems: Threatened hotspots of biodiversity. Biodiversity and Conservation, 22 (10), 2131, 2013.

7. EUROPEAN UNION. Farming in Natura 2000 In harmony with nature. 2017.

8. THE EUROPEAN PARLIAMENT AND THE COUNCIL OF THE EUROPEAN UNION. Regulation (EU) No $1305 / 2013$ on support for rural development by the European Agricultural Fund for Rural Development (EAFRD) and repealing Council Regulation (EC) No 1698/2005, Official Journal of the European Union 2013.

9. DENGLER J., JANIŠOVÁ M., TÖRÖK P., WELLSTEIN C. Biodiversity of Palaearctic grasslands: A synthesis. Agriculture, Ecosystems and Environment, 182, 1, 2014.

10. ROLECEK J., CORNEJ I.I., TOKARJUK A.I. Understanding the extreme species richness of semidry grasslands in east-central Europe: A comparative approach. Preslia, 86 (1), 13, 2014.

11. MRÓZ W. Monitoring of natural habitats. Methodological guide. Part III. Warszawa: GIOŚ. 2012 [In Polish].

12. GALVÁNEK D., LEPŠ J. The effect of management on productivity, litter accumulation and seedling recruitment in a Carpathian mountain grassland. Plant Ecology, 213 (3), 523, 2012.

13. KRYSZAK A., KRYSZAK J., KLARZYŃSKA A. The effect of habitat conditions and utilisation on the development of Arrhenatheretum elatioris. WaterEnvironment-Rural Areas 8 (22), 182, 2008 [In Polish].

14. WRAGE N., STRODTHOFF J., CUCHILLO H.M., ISSELSTEIN J., KAYSER M. Phytodiversity of temperate permanent grasslands: ecosystem services for agriculture and livestock management for diversity conservation. Biodiversity and Conservation, 20 (14), 3317, 2011.

15. NADOLNA L. The effect of restored grassland mowing on the productivity and environmental quality of fallowed grasslands in the Sudetes. Water-Environment-Rural Areas, 3 (27), 103, 2009 [In Polish].

16. NEKROŠIENE R., SKUODIENE R. Changes in floristic composition of meadow phytocenoses, as landscape stability indicators, in protected areas in Western Lithuania. Polish Journal of Environmental Studies, 21 (3), 703, 2012.

17. GALVÁNEK D., LEPŠ J. Changes of species richness pattern in mountain grasslands: Abandonment versus restoration. Biodiversity and Conservation, 17 (13), 3241, 2008.
18. PEINTINGER M., BERGAMINI A. Community structure and diversity of bryophytes and vascular plants in abandoned fen meadows. Plant Ecology, 185 (1), 1, 2006.

19. MYŚLIWY M., BOSIACKA B. Disappearance of Molinio-Arrhenatheretea Meadows Diagnostic Species in the Upper Płonia River Valley (NW Poland). Polish Journal of Environmental Studies, 18 (3), 513, 2009.

20. ŁYSAK D., PIEKUT K.K. Assessment of natural and agriculural values of meadows in Lasica canal valley of Kampinos National Park. Infrastructure and ecology of rural areas, 9, 120, 2010 [In Polish].

21. GIOŚ. Monitoring of species and natural habitats on Natura 2000 Special Areas of Conservation - results of lowland hay meadows 6510 natural habitats monitoring, 17, 2012 [In Polish].

22. CENTALNE BIURO STUDIÓW I PROJEKTÓW WODNO-MELIORACYJNYCH. Development project, object: Mala River Solec. 1971.

23. FILIPEK J. Project for evaluation of meadow and pasture habitats based on fodder value score index. Postępy Nauk Rolniczych 4, 59, 1973 [In Polish].

24. KLAPP E. Meadows and pastures. 4. Edition. Verlag Paul Parey, Berlin und Hamburg 1971 [In German].

25. KULIK M. Changes of biodiversity and species composition of Molinia meadow depending on use method. Polish Journal of Environmental Studies, 23 (3), 773, 2014.

26. MILBERG P., TÄLLE M., FOGELFORS H., WESTERBERG L. The biodiversity cost of reducing management intensity in species-rich grasslands: Mowing annually vs. every third year. Basic and Applied Ecology, 22, 61, 2017.

27. HALADA L', DAVID S., HREŠKO J., KLIMANTOVÁ A., BAČA A., RUSŇÁK T., BURAL M., VADEL L. Changes in grassland management and plant diversity in a marginal region of the Carpathian Mts. in 1999-2015. Science of the Total Environment, 609, 896, 2017.

28. HÜLBER K., MOSER D., SAUBERER N., MAAS B., STAUDINGER M., GRASS V., WRBKA T., WILLNER W. Plant species richness decreased in semi-natural grasslands in the Biosphere Reserve Wienerwald, Austria, over the past two decades, despite agri-environmental measures. Agriculture, Ecosystems \& Environment, 243, 10, 2017.

29. PRUCHNIEWICZ D. Abandonment of traditionally managed mesic mountain meadows affects plant species composition and diversity. Basic and Applied Ecology, 20, 10, 2017.

30. OCKINGER E., ERIKSSON A., SMITH H. Effects of grassland abandonment, restoration and management on butterflies and vascular plants. Biological Conservation, 133, 291, 2006

31. POPTCHEVA K., SCHWARTZE P., VOGEL A., KLEINEBECKER T., HÖLZEL N. Changes in wet meadow vegetation after 20 years of different management in a field experiment (North-West Germany). Agriculture, Ecosystems and Environment, 134 (1-2), 108, 2009.

32. MATUSZKIEWICZ, W. Guide for the determination of plant communities in Poland. Wydawnictwo Naukowe PWN. 2011 [In Polish].

33. LEMKOWSKA B., SOWIŃSKI P., POŻARSKI K. Changes in soil trophic conditions as a treat to natural functions of the Ustnik reserve. Water-Environment-Rural Areas, 1 (29), 79, 2010 [In Polish]. 
34. TOMASZEWSKA K., KOŁODZIEJCZYK K., PODLASKA M. Influence of human activity on the existing of fen peatland in the vicinity of Byczna and its natural values (Opolskie district). Inżynieria Ekologiczna, (29), 216, 2012 [In Polish].

35. OLESZCZUK R., STOCKA I., URBAŃSKI J., HEWELKE E. The technical condition of weir constructions in the sub-irrigation system on the Solec site. Water-Environment-Rural Areas, 17 (1 (57)), 97, 2017 [In Polish].

36. OLESZCZUK R., URBAŃSKI J., GĄSOWSKA M. The influence of morphological changes of small lowland river on discharge rate. Annals of Warsaw University of Life Sciences - SGGW Land Reclamation, 46 (46), 279, 2014.

37. PRAJS B., ANTKOWIAK W. Grassland ecosystems in the varied hydrological and ecological conditions of the
Kulawa river valley. Polish Journal of Environmental Studies, 19 (1), 131, 2010.

38. WASILEWSKI Z. Present status and directions of grassland management according to the requirements of the Common Agricultural Policy. Water-EnvironmentRural Areas, 2 (26), 181, 2009 [In Polish].

39. GDOŚ. Standard Data Form Laki Soleckie PLH140055. 2008.

40. GDOŚ. Standard Data Form Laki Soleckie PLH140055. 2017.

41. KEENLEYSIDE C., RADLEY G., TUCKER G., UNDERWOOD E., HART K., ALLEN B., MENADUE H. Results-based Payments for Biodiversity Guidance Handbook: Designing and implementing results - based agri-environment schemes 2014-2020. London: Institute for European Environmental Policy. 2014. 
